\title{
COVID-19-associated myoclonus in a series of five critically ill patients
}

\author{
Alexander Grieb (D) - Tamara Seitz • Reinhard Kitzberger · Manfred Schmidbauer · Wolfgang Hoepler · \\ Sebastian Baumgartner · Marianna T. Traugott · Erich Pawelka · Mario Karolyi · Georg Strasser · Karolina Knibbe · \\ Hermann Laferl · Alexander Zoufaly · Christoph Wenisch · Stephanie Neuhold
}

Received: 20 January 2021 / Accepted: 4 May 2021 / Published online: 15 June 2021

(C) Springer-Verlag GmbH Austria, part of Springer Nature 2021

\begin{abstract}
Summary
Background In addition to respiratory symptoms, many patients with coronavirus disease 2019 (COVID19) present with neurological complications. Several case reports and small case series described myoclonus in five patients suffering from the disease. The purpose of this article is to report on five critically ill patients with COVID-19-associated myoclonus. Material and methods The clinical courses and test results of patients treated in the study center ICU and those of partner hospitals are described. Imaging, laboratory tests and electrophysiological test results are reviewed and discussed.

Results In severe cases of COVID-19 myoclonus can manifest about 3 weeks after initial onset of symptoms. Sedation is sometimes effective for symptom control but impedes respiratory weaning. No viral particles or structural lesions explaining this phenomenon were found in this cohort.

Conclusion Myoclonus in patients with severe COVID19 may be due to an inflammatory process, hypoxia or GABAergic impairment. Most patients received treat-
\end{abstract}

The authors A. Grieb and T. Seitz contributed equally to this work.

A. Grieb, BScMed $(\bowtie) \cdot$ T. Seitz $\cdot$ R. Kitzberger $\cdot$ W. Hoepler . S. Baumgartner $\cdot$ M. T. Traugott $\cdot$ E. Pawelka $\cdot$ M. Karolyi $\cdot$ H. Laferl · A. Zoufaly · C. Wenisch · S. Neuhold 4th Medical Division for Infectious Disease Medicine and Tropical Medicine, Klinik Favoriten, Pav. C, Kundtratstr. 3, 1100 Vienna, Austria

alexander.grieb@gmx.at

\section{Schmidbauer}

Head-Nerve Center, Medical Faculty, Sigmund Freud

University, Freudplatz 2, 1020 Vienna, Austria

G. Strasser · K. Knibbe

1st Medical Division for Cardiology, Klinik Donaustadt,

Langobardenstr. 122, 1220 Vienna, Austria ment with antiepileptic or anti-inflammatory agents and improved clinically.

Keywords SARS-CoV-2 $\cdot$ Movement disorders $\cdot$ Case series $\cdot$ Intensive care $\cdot$ Sedation

\section{Introduction}

During the ongoing pandemic of coronavirus disease 2019 (COVID-19) caused by severe acute respiratory syndrome coronavirus 2 (SARS-CoV-2), most patients presented with upper or lower respiratory tract symptoms; however, with time reports of a variety of different neurological symptoms were described, including anosmia [1], ageusia [1], myalgia [2] and headaches [3] and more severe complications including ischemic stroke $[2,4,5]$, sinus venous thrombosis [3, 5], Miller-Fisher syndrome [5-7] and GuillainBarré syndrome (GBS) [3, 8, 9]. In this report, five patients with severe courses of COVID-19 associated with generalized myoclonus are presented.

\section{Material and methods}

Cases were retrospectively identified by contacting intensive care units treating patients with severe COVID19 within the local municipal hospital system (Wiener Gesundheitsverbund). According to the guidelines of the local ethics committee (Ethikkommission der Stadt Wien), no formal institutional review was necessary for this publication.

\section{Case 1}

A 52-year-old man with a history of coronary artery disease $(C A D)$, peripheral artery disease (PAD), arterial hypertension, type 2 diabetes mellitus, dyslipidemia and obesity presented to the clinic with a 4- 
Table 1 Patient characteristics, clinical course and examination findings

\begin{tabular}{|c|c|c|c|c|c|}
\hline & Patient 1 & Patient 2 & Patient 3 & Patient 4 & Patient 5 \\
\hline $\begin{array}{l}\text { Age at presen- } \\
\text { tation (years) }\end{array}$ & 52 & 64 & 66 & 47 & 85 \\
\hline $\begin{array}{l}\text { Sex assigned at } \\
\text { birth }\end{array}$ & Male & Male & Female & Male & Male \\
\hline $\begin{array}{l}\text { Pre-existing } \\
\text { neurological } \\
\text { conditions }\end{array}$ & None & None & None & None & None \\
\hline $\begin{array}{l}\text { Other pre-existing } \\
\text { conditions }\end{array}$ & $\begin{array}{l}\text { Coronary artery disease, pe- } \\
\text { ripheral artery disease, arterial } \\
\text { hypertension, type } 2 \text { diabetes } \\
\text { mellitus, dyslipidemia, obesity }\end{array}$ & None & Anxiety disorder & None & Arterial hypertension \\
\hline Substance use & Former smoker, social drinker & None & Social drinker & Social drinker & Social drinker \\
\hline $\begin{array}{l}\text { Highest demand } \\
\text { for respiratory } \\
\text { support (room } \\
\text { air, low-flow 02, } \\
\text { high-flow 02, } \\
\text { NIV, mechanical } \\
\text { ventilation) }\end{array}$ & $\begin{array}{l}\text { Mechanical ventilation via en- } \\
\text { dotracheal tube and tracheal } \\
\text { cannula }\end{array}$ & $\begin{array}{l}\text { Mechanical ventilation } \\
\text { via endotracheal tube } \\
\text { and tracheal cannula }\end{array}$ & $\begin{array}{l}\text { Mechanical ventilation via } \\
\text { endotracheal tube and } \\
\text { tracheal cannula }\end{array}$ & $\begin{array}{l}\text { Mechanical ven- } \\
\text { tilation via en- } \\
\text { dotracheal tube }\end{array}$ & $\begin{array}{l}\text { Mechanical ventilation via endo- } \\
\text { tracheal tube }\end{array}$ \\
\hline $\begin{array}{l}\text { Catecholamine } \\
\text { support }\end{array}$ & Yes & Yes & Yes & Yes & Yes \\
\hline Antiviral therapy & $\begin{array}{l}\text { Recombinant human ACE2/ } \\
\text { Placebo }\end{array}$ & Hydroxychloroquine & $\begin{array}{l}\text { Aciclovir (due to inter- } \\
\text { mittent herpes labialis) }\end{array}$ & Remdesivir & Remdesivir \\
\hline $\begin{array}{l}\text { Anti-inflammatory } \\
\text { therapy }\end{array}$ & $\begin{array}{l}\text { Methylprednisolone, intravenous } \\
\text { immunoglobulins }\end{array}$ & Prednisolone & None & Prednisolone & Dexamethasone \\
\hline $\begin{array}{l}\text { Antimicrobial } \\
\text { therapy }\end{array}$ & $\begin{array}{l}\text { Ceftazidime, cefuroxime, } \\
\text { Piperacillin/tazobactam, dapto- } \\
\text { mycin, meropenem, vancomycin }\end{array}$ & $\begin{array}{l}\text { Piperacillin/tazobactam, } \\
\text { caspofungin }\end{array}$ & $\begin{array}{l}\text { Caspofungin, ceftriaxone, } \\
\text { clotrimazole (topical), } \\
\text { levofloxacin, piperacillin/ } \\
\text { tazobactam, tigecycline, } \\
\text { doxycycline, ceftazidime/ } \\
\text { avibactam, azithromycin, } \\
\text { linezolid }\end{array}$ & Ceftriaxone & $\begin{array}{l}\text { Cefuroxim, piperacillin/ } \\
\text { tazobactam, meropenem, cef- } \\
\text { tazidime/avibactam, liposomal } \\
\text { amphotericin B, topical nystatin }\end{array}$ \\
\hline $\begin{array}{l}\text { Other medical } \\
\text { treatment }\end{array}$ & $\begin{array}{l}\text { Sedatives, analgesics including } \\
\text { opiates, } \\
\text { antipyretics, } \\
\text { vasopressor, } \\
\text { diuretics, } \\
\text { proton pump inhibitor, } \\
\text { antipsychotics, } \\
\text { beta blockers, insulin, ASA, } \\
\text { anticonvulsants, tetrabenazine, } \\
\text { amiodarone }\end{array}$ & $\begin{array}{l}\text { Sedatives, analgesics } \\
\text { including opiates, } \\
\text { antipyretics, } \\
\text { vasopressor, } \\
\text { diuretics, } \\
\text { proton pump inhibitor, } \\
\text { antipsychotics, } \\
\text { beta blockers, insulin, } \\
\text { antiarrhythmics }\end{array}$ & $\begin{array}{l}\text { Sedatives, analgesics } \\
\text { including opiates, } \\
\text { antipyretics, } \\
\text { vasopressor, } \\
\text { diuretics, } \\
\text { proton pump inhibitor, } \\
\text { antipsychotics, } \\
\text { beta blockers, } \\
\text { antiarrhythmics }\end{array}$ & $\begin{array}{l}\text { Sedatives, anal- } \\
\text { gesics including } \\
\text { opiates, } \\
\text { antipyretics, } \\
\text { vasopressor, } \\
\text { diuretics, } \\
\text { proton pump } \\
\text { inhibitor, anticon- } \\
\text { vulsants }\end{array}$ & $\begin{array}{l}\text { Sedatives, analgesics including } \\
\text { opiates, } \\
\text { antipyretics, } \\
\text { vasopressor, } \\
\text { diuretics, } \\
\text { proton pump inhibitor, } \\
\text { antipsychotics, } \\
\text { beta blockers, insulin, antiemet- } \\
\text { ics, antidepressants, ASA, an- } \\
\text { ticonvulsants, tetrabenazine, } \\
\text { amiodarone }\end{array}$ \\
\hline $\begin{array}{l}\text { Description of } \\
\text { myoclonus }\end{array}$ & $\begin{array}{l}\text { Generalized myoclonic jerks } \\
\text { involving all four extremities, the } \\
\text { trunk and the head and muscles }\end{array}$ & $\begin{array}{l}\text { Generalized myoclonic } \\
\text { jerks involving the upper } \\
\text { extremities, the head } \\
\text { and facial muscles, } \\
\text { generalized rigor }\end{array}$ & $\begin{array}{l}\text { Myoclonic jerks involv- } \\
\text { ing mainly the upper } \\
\text { extremities and the head, } \\
\text { generalized rigor, motoric } \\
\text { aphasia }\end{array}$ & $\begin{array}{l}\text { Myoclonic jerks } \\
\text { involving mainly } \\
\text { the head and the } \\
\text { upper extremities }\end{array}$ & $\begin{array}{l}\text { Myoclonic jerks involving the face } \\
\text { and shoulders }\end{array}$ \\
\hline $\begin{array}{l}\text { First presentation } \\
\text { of myoclonus } \\
\text { after symptom } \\
\text { onset }\end{array}$ & 22 days & 26 days & 19 days & 20 days & 26 days \\
\hline $\begin{array}{l}\text { Duration of my- } \\
\text { oclonus }\end{array}$ & 27 days & 9 days & 6 days & 1 day & 1 day \\
\hline $\begin{array}{l}\text { Other neurologi- } \\
\text { cal findings }\end{array}$ & $\begin{array}{l}\text { Cognitive dysfunction, severe } \\
\text { dysphagia, delirium }\end{array}$ & $\begin{array}{l}\text { Cognitive dysfunction, } \\
\text { dysphagia, delirium }\end{array}$ & $\begin{array}{l}\text { Cognitive Dysfunction, } \\
\text { delirium, neck stiffness, } \\
\text { dysphagia }\end{array}$ & $\begin{array}{l}\text { Dysphagia, sym- } \\
\text { metric muscle } \\
\text { weakness, es- } \\
\text { pecially upper } \\
\text { extremities }\end{array}$ & Coma, reduced muscle tone \\
\hline CCT findings & Unremarkable & Unremarkable & Unremarkable & Unremarkable & $\begin{array}{l}\text { Small subcortical hypointensity } \\
\text { in the left frontal lobe consistent } \\
\text { with an old postischemic lesion }\end{array}$ \\
\hline cMRl findings & $\begin{array}{l}\text { Small subcortical hypointensity } \\
\text { in the right frontal lobe consis- } \\
\text { tent with a post-ischemic lesion }\end{array}$ & Unremarkable & Not done & Not done & Not done \\
\hline
\end{tabular}


Table 1 (Continued)

\begin{tabular}{|c|c|c|c|c|c|}
\hline & Patient 1 & Patient 2 & Patient 3 & Patient 4 & Patient 5 \\
\hline EEG findings & $\begin{array}{l}\text { Generalized slowing of back- } \\
\text { ground activity without focal } \\
\text { epileptic potentials }\end{array}$ & Not done & Not done & Unremarkable & $\begin{array}{l}\text { Generalized slowing of back- } \\
\text { ground activity without focal } \\
\text { epileptic potentials }\end{array}$ \\
\hline \multirow[t]{6}{*}{ CSF findings } & $\begin{array}{l}\text { Cells: } 2 \text { cells/ } / \mathrm{l} \\
\text { Protein: } 82.2 \mathrm{mg} / \mathrm{dl}\end{array}$ & $\begin{array}{l}\text { Cells } 49 \text { cells/ } / \mu \mathrm{l} \\
\text { Protein: } 71.3 \mathrm{mg} / \mathrm{dl}\end{array}$ & $\begin{array}{l}\text { Cells: } 7 \text { cells/ } / \mu \mathrm{l} \\
\text { Protein: } 31.1 \mathrm{mg} / \mathrm{dl}\end{array}$ & \multirow[t]{6}{*}{ Not done } & \multirow[t]{6}{*}{ Not done } \\
\hline & Broad-spectrum PCR: negative & $\begin{array}{l}\text { Broad-spectrum PCR: } \\
\text { negative }\end{array}$ & $\begin{array}{l}\text { Broad-spectrum PCR: } \\
\text { negative }\end{array}$ & & \\
\hline & HSV, West Nile, TBE negative & $\begin{array}{l}\text { HSV, West Nile, TBE } \\
\text { negative }\end{array}$ & $\begin{array}{l}\text { HSV, West Nile, TBE } \\
\text { negative }\end{array}$ & & \\
\hline & SARS-CoV-2 negative & SARS-CoV-2 negative & SARS-CoV-2 negative & & \\
\hline & CSF culture: no growth & \multirow[t]{2}{*}{ CSF culture: no growth } & \multirow[t]{2}{*}{ CSF culture: no growth } & & \\
\hline & $\begin{array}{l}\text { Autoimmune encephalitis au- } \\
\text { toantibodies negative (Hu, } \\
\text { Yo, Ri, Tr, CV2, amphiphysin, } \\
\text { Ma1/2, PKCgamma, CARPVIII, } \\
\text { ARHGAP26, SOX1, GAD65, } \\
\text { AK5, Homer3, anti-NMDA, } \\
\text { anti-AMPAR, anti-GABA(B)R, } \\
\text { anti-LGl1, anti-CASPR2) }\end{array}$ & & & & \\
\hline $\begin{array}{l}\text { NIV non-invas } \\
\text { resonance im } \\
\text { cephalitis, SA } \\
\text { tein VIII, } A R H C \\
\text { zyme 5, anti-I } \\
\text { ma-aminobut }\end{array}$ & $\begin{array}{l}\text { tilation, ACE2 angiotensin-co } \\
\text { EEG electroencephalography, } \\
\text { /-2 Severe acute respiratory s } \\
\text { 2ho GTPase activating protein } \\
\text { anti-N-Methyl-D-aspartic acid } \\
\text { d B receptor, anti-LGI1 anti-le }\end{array}$ & $\begin{array}{l}\text { ng enzyme, } A S A \text { ace } \\
\text { erebrospinal fluid, } P \\
\text { me coronavirus 2, } P \\
\text { SOX1 SRY-related HN } \\
\text {-AMPAR anti- } \alpha \text {-amin } \\
\text {-rich, glioma inactiv }\end{array}$ & $\begin{array}{l}\text { gene } 1, \text { GAD } 65 \mathrm{gl} \\
\text { droxy-5-methyl-4 } \\
\text { anti-CASPR2 anti }\end{array}$ & $\begin{array}{l}\text { acid decarb } \\
\text { olepropionic } \\
\text { tin-associat }\end{array}$ & $\begin{array}{l}\text { hy, } c M R I \text { cerebral magnetic } \\
\text { virus, TBE tick-borne en- } \\
\text { nic anhydrase-related pro- } \\
65, A K 5 \text { adenylate kinase isoen } \\
\text { ceptor, anti-GABA(B)R anti-gam } \\
\text { in } 2\end{array}$ \\
\hline
\end{tabular}

day history of fever and nonproductive cough. He had been tested positive for SARS-CoV-2 at another hospital the day before and was brought in via an ambulance due to progressive shortness of breath. For treatment of COVID-19, he received noninvasive respiratory support, including high flow nasal cannula (HFNC) and noninvasive ventilation (NIV), prednisone and recombinant human angiotensin converting enzyme 2 (rhACE2) or placebo within a clinical trial. Despite this the respiratory situation deteriorated and he required intubation and mechanical ventilation on the seventh day after admission. Adequate sedation could only be achieved with a combination of high doses of propofol, s-ketamine and remifentanil.

After 9 days of ventilation the patient was extubated. Within hours, he developed generalized myoclonus involving all four extremities (more pronounced in the upper than in the lower extremities), the trunk and whole face. This interfered with breathing to such a degree that he had to be reintubated on the same day. During this episode, the patient was clearly conscious and unable to control these movements. Despite sedation with remifentanil, propofol, midazolam and dexmedetomidine, the myoclonic jerks were only insufficiently controlled. Cerebral computed tomography (CT) showed no significant pathology and cerebral magnetic resonance imaging (MRI) only revealed a single small subcortical hypointensity in the right frontal lobe consistent with a postischemic lesion. Lumbar puncture demonstrated impaired blood barrier function and intrathecal immunoglobulins with no evidence of monoclonal bands but normal lactate and glucose levels. Cerebrospinal fluid (CSF) was negative for SARSCoV-2 and West Nile virus and broad-spectrum PCR (Biofire ${ }^{\circledR}$ Meningitis/Encephalitis ME panel, BioFire Diagnostics/Biomerieux, Salt Lake City, UT) did not detect any infective agents. No autoantibodies commonly associated with autoimmune encephalitis were identified in the patient's CSF (see Table 1).

The electroencephalogram was remarkable only for diffuse cerebral dysfunction without focal epileptic potentials. A repeat MRI did not show any progression or new pathological findings. Treatment with levetiracetam, valproic acid, perampanel and tetrabenazine did not sufficiently control the patient's myoclonus, which greatly impaired efforts of respiratory weaning. The symptoms could be triggered by multisensory stimuli (auditive and tactile) or voluntary movement. After high-dose steroids (methylprednisolone $800 \mathrm{mg} /$ day for 5 days) did not lead to any improvements, intravenous immunoglobulin $(40 \mathrm{~g}$ daily) was administered over 5 days, also leading to no discernible effect.

Tracheotomy was performed and over several weeks the patient was slowly weaned off sedation. Myoclonus ceased completely under treatment with valproic acid, perampanel and lorazepam 27 days after onset. The patient's clinical status slowly improved and he was transferred to another ICU for further care. At the time of transfer, the patient had been free of myoclonic jerks for 6 days but continued to suffer from severe dysphagia, cognitive dysfunction and generalized weakness. 
Myoclonus did not recur when sedation was reduced. The patient continued to suffer from delirium and his stay was further complicated by several episodes of cardiac arrest due to ventricular arrhythmia, ventilator associated pneumonia and gastrointestinal bleeding. More than 100 days after initial presentation, the patient still requires intensive care.

\section{Case 2}

A 64-year-old man with an unremarkable medical history presented to hospital with confirmed COVID-19 and diarrhea, cough and fever for 3 days. Due to progressive dyspnea and respiratory failure despite noninvasive respiratory support, he was admitted to the ICU. The patient had to be intubated 2 days later, was placed on mechanical ventilation and several cycles of prone positioning were performed. For treatment of COVID-19, he received a 10-day course of high-dose prednisone and hydroxychloroquine within a clinical trial. Furthermore, due to rising levels of inflammation markers, he received empirical antibiotic therapy with piperacillin/tazobactam. A central catheter related bloodstream infection due to Candida albicans fungemia was successfully treated with caspofungin. Adequate sedation could only be achieved with a combination of high doses of propofol, s-ketamine and remifentanil. Due to acute renal failure, continuous venovenous hemofiltration was necessary for 9 days.

After 6 days of prone positioning sedation was reduced. The patient developed severe delirium, for which therapy with quetiapine and dexmedetomidine was started. Tracheotomy was performed to facilitate weaning from respiratory support. After further reduction of sedation, the patient developed symmetrical myoclonus of both upper extremities and the head, facial twitches and a remarkable rigor of all extremities with predominance of the arms.

Cerebral CT and MRI showed no significant pathology. Lumbar puncture demonstrated a slightly elevated cell count $(49$ cells $/ \mu \mathrm{l})$ and protein $(713 \mathrm{mg} / \mathrm{l})$. There was no evidence of monoclonal bands and normal lactate and glucose levels were found. Cerebrospinal fluid was negative for SARS-CoV-2, West Nile virusand Herpes simplex. Broad-spectrum PCR (Biofire ${ }^{\circledR}$ Meningitis/Encephalitis ME panel) did not detect any infective agents.

Push dose midazolam and propofol controlled the neurological symptoms only briefly, rendering a deeper level of sedation necessary. After 6 days reduction of sedation, the patient slowly regained consciousness and no further myoclonic events were noticed; however, the patient suffered from severe dysphagia, cognitive dysfunction and generalized weakness. Electrophysiological tests were unavailable at the time as the patient was still infectious and 26 days after ICU admission, he was transferred to a neurological rehabilitation department. After 5 weeks of rehabilitation he was discharged home in a good functional status.

\section{Case 3}

A 67-year-old woman with confirmed COVID-19 was admitted for dyspnea due to respiratory infection. She had to be transferred to the ICU for acute hypoxic respiratory failure and received noninvasive respiratory support. The patient had to be intubated, placed on mechanical ventilation and prone positioning had to be initiated almost immediately after intubation due to persistent severe hypoxia. She received azithromycin and doxycycline. Adequate sedation could only be achieved with a combination of propofol, s-ketamine, midazolam and remifentanil.

The patient had to be kept in a prone position for a total of 10 days until slow clinical improvement and simultaneous improvement of inflammation markers were noted. Weaning from the ventilator was initiated and the patient started to develop myoclonic side to side jerks of the head, facial twitches and generalized rigor, as well as hypokinesia. Simultaneously, Herpes labialis-type lesions developed on the lower lip. A lumbar puncture showed mild CSF leukocytosis and lymphomonocytosis. Broad-spectrum PCR of CSF ruled out the presence of Herpes simplex type 1 virus or SARS-CoV-2 in the CSF. Additionally, cerebral CT showed no abnormalities. The symptoms resolved spontaneously over the course of the following 6 days. No further myoclonic events were noticed.

The patient was extubated a few days later but had to be reintubated due to weakness, dysphagia with inability to control saliva and worsening hypoxia after 4 days. Tracheostomy was performed, after which the patient was successfully weaned off the ventilator over the course of several weeks. After 55 days in the ICU, the patient was transferred to the regular ward and later to the rehabilitation ward. Persistent neurological symptoms (mainly weakness of the upper and lower extremities and gait disorder) were noted but improved with physical therapy. At discharge, after a total of 106 days in the hospital, the patient was mobile with walking sticks.

\section{Case 4}

A 47-year-old healthy man presented to the clinic with a 9-day history of fever, nonproductive cough, myalgia and progressive shortness of breath. Diagnosis of COVID-19 was established via PCR. Despite high-flow nasal oxygen therapy, his respiratory situation deteriorated further, and he was admitted to the intensive care unit. He received NIV, prednisone, convalescent plasma on 3 consecutive days and remdesivir. He required intubation and mechanical ventilation 6 days after ICU admission. Adequate sedation could only be achieved with high doses of propofol, s-ketamine, midazolam and remifentanil. 
While the respiratory situation quickly improved, after the reduction of sedative agents, the patient started to develop myoclonic side to side jerks of the head and a symmetrical myoclonus of both upper extremities. Therapy with levetiracetam was unsuccessful. The myoclonus only resolved after initiation of a continuous midazolam infusion. A cerebral CT showed no significant pathology and EEG on the same day and 2 weeks later showed no abnormalities. Midazolam was discontinued 2 days later, levetiracetam was tapered and discontinued 12 days after initial onset of myoclonus.

The patient was successfully extubated after 14 days on the ventilator. No further myoclonic events occurred, but the patient experienced severe dysphagia and bilateral weakness of the upper extremities. After an ICU stay of 20 days, he was transferred to a neurological rehabilitation department. At the time of transfer, he was unable to lift his arms, while no sensory deficit was noted; however, after 3 weeks of rehabilitation, he was discharged with completely restored neurological function.

\section{Case 5}

An 85-year-old man with a history of arterial hypertension presented to a municipal hospital with acute onset of shortness of breath and fever. He was transferred to the ICU with ongoing NIV after a positive PCR for SARS-CoV-2. He received dexamethasone, convalescent plasma on 3 consecutive days and remdesivir. He was intubated and mechanically ventilated due to respiratory failure and fatigue 3 days after admission. During his stay, he exhibited a variety of hemodynamically relevant dysrhythmias including sinus bradycardia, junctional rhythm, tachycardic atrial fibrillation and ventricular couplets. On two different occasions, the patient experienced cardiac arrest and required advanced life support including defibrillation and intravenous epinephrine. After these events, a cerebral CT showed no signs of hypoxic damage or other significant abnormalities.

The patient developed ventilator-associated pneumonia, with a broad spectrum PCR from tracheal secretions detecting Serratia marcescens. When the SARS-CoV-2 viral load in PCR testing was below the cut-off value $(100,000$ copies/ml agreed on in this institution) and the patient no longer exhibited any signs or symptoms of active SARS-CoV-2 infection, the patient was no longer considered to be infectious. He was therefore transferred to a non-COVID ICU for further treatment.

In spite of successful treatment of ventilator-associated pneumonia, weaning from the ventilator was unsuccessful due to hypercapnia and persisting coma even with minimal sedation. Myoclonus of the face and shoulders was noticed 26 days after initial presentation. A cerebral CT showed only a small subcortical hypointensity in the left frontal lobe consistent with an old postischemic lesion. No other pathology of the CNS was found. The two EEGs demonstrated diffuse cerebral dysfunction with no seizure-related abnormalities. Propofol and remifentanil were increased and levetiracetam was started, which led to complete resolution of myoclonus. Due to a lack of neurological improvement and continuous deterioration of the patient's respiratory function, he was placed on comfort care. He died 5 days after initial onset of myoclonus. In accordance with the wishes of the patients' family an autopsy was not performed.

\section{Results}

All five patients presented with a severe course of COVID-19 and required intensive care with mechanical ventilation and high doses of sedation. None of the patients had known pre-existing neurological conditions. In all cases, the first presentation of myoclonus occurred after reduction of the sedative medication (see Table 1). The median duration for the first appearance of myoclonus was 22 days after symptom onset (range 19-31 days). Of the five patients three suffered from a myoclonus of the upper extremities only, one of upper and lower extremities and one of the shoulders only. In all cases myoclonus of the head and the facial muscles was seen. In two cases, a generalized rigor was described. Cerebral imaging showed no major abnormalities in any of the patients and EEG demonstrated no epileptiform activities. As patients were still infectious during the disease not all examinations including MRI and electrophysiological testing were easily feasible. Antibodies for autoimmune encephalitis were negative. In three of the five patients lumbar puncture was performed and demonstrated elevated protein in two of the three patients with a variable cell count. No pathogen could be detected with PCR and no growth in cultures was seen. The SARS-CoV-2 could not be detected in any CSF samples in this case series.

Different therapeutic strategies were employed, including antiepileptic therapy, high-dose steroids and intravenous immunoglobulins. Tocilizumab was not in use at the study centers at the time. In all patients, the myoclonus resolved after a mean duration of 8.8 days (range 1-27 days) with variable response to sedation. All patients suffered from other neurological symptoms during their stay in the ICU, including dysphagia, severe muscle weakness and delirium; however, these conditions might be explained by the prolonged ICU stay and high doses of sedative medication.

\section{Discussion}

Several cases and case series describing COVID-19 patients with myoclonus have been published to date [10]. The severity of respiratory disease was variable and ranged from asymptomatic cases only diagnosed 
via serology [11] to critically ill patients requiring mechanical ventilation $[12,13]$. A literature review found that $53.3 \%$ of patients with myoclonus and COVID19 required ICU admission [10]. This suggests that hypoxia, among other components of toxic metabolic encephalopathy, might be a contributing factor in the pathogenesis of myoclonus [14]; however, considering the number of cases without pulmonary involvement [10], additional mechanisms must be considered.

No viral RNA was detected in the CSF of the patients sampled, which is consistent with the published literature [10]. While this suggests no direct neuronal damage exerted by viral replication within the CNS in these patients, other inflammatory mechanisms may be implicated. In patients with post-COVID fatigue and dysexecutive syndrome, transcranial magnetic stimulation demonstrated impairment of GABA-ergic intracortical circuits $[15,16]$.

The latency of myoclonus after onset of COVID symptoms was a mean of 22.6 days (interquartile range, IQR 19.5-26 days) in this series. This is consistent with an autoinflammatory mechanism and marginally higher than the latency in the cases published to date, which is 13 days (IQR 11-21 days) [10]. This may be explained by the heavy sedation and use of neuromuscular blockade in this series, which might have caused a delay in recognition of motor symptoms. Direct injury due to viral replication might explain the transient symptoms but no viral RNA of SARS-CoV-2 was found in the CSF and the symptoms persisted long after viral clearance from the blood and respiratory tract.

No antineuronal antibodies were found in the CSF of the patients in this series who underwent sampling. Out of 10 patients in the literature only 1 was found to have demonstrable levels of antineuronal antibodies in CSF [10, 17]. Imaging modalities showed no lesions in the brain parenchyma and clinical examinations demonstrated no focal symptoms including motor or sensory deficits, which reduces the likelihood of structural lesions, such as stroke, necrosis and demyelinating processes as a cause.

Other common causes of CNS disturbances including stroke, intracranial bleeding, intracerebral lesions or tumors, viral encephalitis, GBS, Borrelia or Treponema infection, vasculitis were excluded by a wide range of tests and examinations (Table 1). While some medications, including opioids, benzodiazepines and antiarrhythmic drugs have been described to trigger myoclonus, none of the drugs given in this series could be identified as a likely cause of the symptoms with reasonable clinical suspicion in all five patients. Furthermore, most of these agents (listed in Table 1) are commonly used in critical care and only rarely cause these side effects.

The major limitation of this study is the small sample size; however, this report may raise awareness for a rare complication of COVID-19 possibly underreported so far. The significant number of cases at the study center (4/87 ICU patients at the time) suggests the possibility of a larger number of unreported cases. Furthermore, electrophysiological testing was limited to EEG in this series, which was only performed in three of five cases, due to reduced availability of other modalities, such as triggered and jerk-locked back-averaged poly-electromyography, and jerk-locked backaveraged EEG, during the COVID-19 pandemic. In some cases, these modalities were judged to be of no clinical relevance by the consulting neurologists. Clinicians should keep the phenomenon of COVID19 associated myoclonus in mind when a patient with COVID-19 presents with a movement disorder.

\section{Conclusion}

A possible etiology of myoclonus in patients with COVID-19 is neuronal dysfunction caused by a postinfectious inflammatory process. This theory is supported by the fact that the symptoms were reversible in all cases and intrathecal immunoglobulins were detected. Furthermore, the onset of symptoms with some latency after a viral infection is typical $[14,15]$.

While both antiepileptic drugs and immunomodulatory therapy led to clinical improvements in this series, this effect cannot be meaningfully distinguished from a self-limiting course of disease. Additionally, the use of sedatives may have further impeded this distinction. Despite unclear benefits, similar attempts at treatment have been described in the literature [10, 12]. Treatment of myoclonus in patients with COVID19 should receive careful consideration by expert clinicians.

Author Contribution All authors contributed to the study conception and design. The first draft of the manuscript was written by Alexander Grieb and Tamara Seitz and all authors commented on previous versions of the manuscript. All authors read and approved the final manuscript.

\section{Declarations}

Conflict of interest A. Grieb, T. Seitz, R. Kitzberger, M.Schmidbauer, W. Hoepler, S. Baumgartner, M.T. Traugott, E. Pawelka, M. Karolyi, G. Strasser, K. Knibbe, H. Laferl, A. Zoufaly, C. Wenisch and S. Neuhold declare that they have no competing interests. The authors declare that no funding was received for this publication. The authors further declare that they have no financial or personal relationships with other people or organizations that could have inappropriately influenced this study.

Ethical standards No ethics approval and no informed consent was necessary in accordance with the local ethics committee. All procedures followed were in accordance with the ethical standards of the responsible committee on human experimentation (institutional and national) and with the Helsinki Declaration of 1975, as revised in 2008. 


\section{References}

1. Vaira LA, Salzano G, Deiana G, de Riu G. Anosmia and Ageusia: commonfindingsin COVID-19 patients. Laryngoscope. 2020;130(7):1787.

2. Mao L, Wang M, Chen S, He Q, Chang J, Hong C, et al. Neurological manifestations of hospitalized patients with COVID-19 in Wuhan, China: a retrospective case series study. 2020.

3. Li Y, Li M, Wang M, Zhou Y, Chang J, Xian Y, et al. Acute cerebrovascular disease following COVID-19: a single center, retrospective, observational study. Stroke Vasc Neurol. 2020; https://doi.org/10.1136/svn-2020-000431.

4. OxleyTJ, Mocco J, MajidiS, Kellner CP, Shoirah H, Singh IP, et al. Large-vessel stroke as a presenting feature of Covid-19 in theyoung. NEngl J Med. 2020;382(20):e60.

5. Ellul MA, Benjamin L, Singh B, LantS, Michael BD, EastonA, et al. Neurological associations of COVID-19. Lancet Neurol. 2020;19(9):767-83.

6. Gutiérrez-Ortiz C, Méndez-Guerrero A, Rodrigo-ReyS, San Pedro-Murillo E, Bermejo-Guerrero L, Gordo-Mañas R, et al. Miller Fisher syndrome and polyneuritis cranialis in COVID-19. Neurology. 2020;95(5):e601-e5.

7. Senel M, Abu-Rumeileh S, Michel D, Garibashvili T, Althaus K, Kassubek J, et al. Miller-Fisher syndrome after COVID-19: neurochemical markers as an early sign of nervous system involvement. Eur J Neurol. 2020; https://doi. org/10.1111/ene.14473.

8. Asadi-Pooya AA, Simani L. Central nervous system manifestations of COVID-19: A systematic review. J Neurol Sci. 2020;413:116832.

9. Finsterer J, Scorza F, Fiorini A. SARS-CoV-2 associated Guillain-Barre syndrome in 62 patients. Eur J Neurol. 2020; https://doi.org/10.1111/ene.14544.

10. Chan JL, Murphy KA, Sarna JR. Myoclonus and cerebellar ataxia associated with COVID-19: a case report and sys- tematic review. J Neurol. 2021; https://doi.org/10.1007/ s00415-021-10458-0.

11. ElOtmaniH, MoutaouakilF, OuazzaniM, MjahedK.Isolated generalized myoclonus immune-mediated by SARS-CoV2: an illustrative videotaped case. Neurol Sci. 2021; https:// doi.org/10.1007/s10072-021-05164-8.

12. Anand P, Zakaria A, Benameur K, Ong C, Putman M, O'Shea S, et al. Myoclonus in patients with Coronavirus disease 2019: a multicenter case series. Crit Care Med. 2020;48(11):1664-9.

13. Cuhna P, Herlin B, Vassilev K, Kas A, Lehericy S, Worbe Y, et al. Movement disorders as a new neurological clinical picture in severe SARS-CoV-2 infection. Eur J Neurol. 2020;27(12):e88-e90.

14. Frontera JA, Melmed K, Fang T, Granger A, Lin J, YaghiS, et al. Toxic metabolic encephalopathy in hospitalized patients with COVID-19. Neurocrit Care. 2021; https://doi.org/10. 1007/s12028-021-01220-5.

15. Versace V, Sebastianelli L, Ferrazzoli D, Romanello R, Ortelli P, Saltuari L, et al. Intracortical GABAergic dysfunction in patients with fatigue and dysexecutive syndrome after COVID-19. Clin Neurophysiol. 2021;132(5):1138-43.

16. Ortelli P, Ferrazzoli D, Sebastianelli L, Engl M, Romanello R, Nardone R, et al. Neuropsychological and neurophysiological correlates of fatigue in post-acute patients with neurological manifestations of COVID-19: Insights into a challenging symptom. J Neurol Sci. 2021;420:117271.

17. Grimaldi S, Lagarde S, Harlé J-R, Boucraut J, Guedj E. Autoimmune encephalitis concomitant with SARS-coV-2 infection: insight from 18F-FDGPET imaging and neuronal autoantibodies. J Nucl Med. 2020;61(12):1726-9.

Publisher's Note Springer Nature remains neutral with regard to jurisdictional claims in published maps and institutional affiliations. 